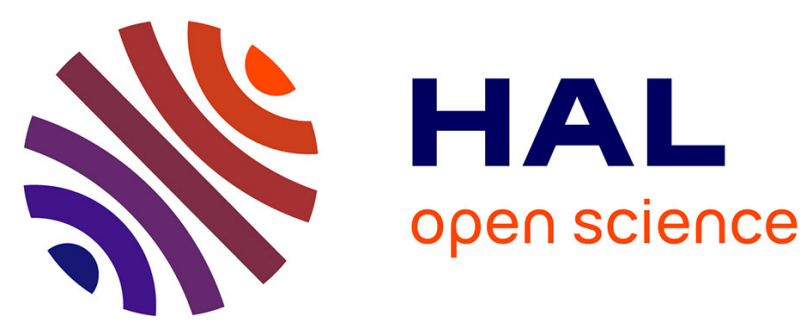

\title{
MLVA and SNP analysis identified a unique genetic cluster in Bulgarian strains
}

M. Antwerpen, D. Ilin, E. Georgieva, H. Meyer, E. Savov, D. Frangoulidis

\section{To cite this version:}

M. Antwerpen, D. Ilin, E. Georgieva, H. Meyer, E. Savov, et al.. MLVA and SNP analysis identified a unique genetic cluster in Bulgarian strains. European Journal of Clinical Microbiology and Infectious Diseases, 2011, 30 (7), pp.923-930. 10.1007/s10096-011-1177-2 . hal-00664190

\section{HAL Id: hal-00664190 https://hal.science/hal-00664190}

Submitted on 30 Jan 2012

HAL is a multi-disciplinary open access archive for the deposit and dissemination of scientific research documents, whether they are published or not. The documents may come from teaching and research institutions in France or abroad, or from public or private research centers.
L'archive ouverte pluridisciplinaire HAL, est destinée au dépôt et à la diffusion de documents scientifiques de niveau recherche, publiés ou non, émanant des établissements d'enseignement et de recherche français ou étrangers, des laboratoires publics ou privés. 


\section{$1 \quad$ MLVA- and SNP analysis identified an unique genetic cluster} in Bulgarian Bacillus anthracis strains

3

4

5

M. Antwerpen ${ }^{1 *}$, D. Ilin², E. Georgieva², H. Meyer ${ }^{1}$, E. Savov ${ }^{2}$ and D. Frangoulidis ${ }^{1}$

6

${ }^{1}$ Bundeswehr Institute of Microbiology, Munich, Germany

$7 \quad{ }^{2}$ Department of Clinical Microbiology, Military Medical Academy, Sofia, Republic of Bulgaria

8

$9 \quad *$ corresponding author: markusantwerpen@bundeswehr.org

10 Bundeswehr Institute of Microbiology

11 Neuherbergstr. 11

1280937 Muenchen

13 Germany

15 European Journal of Clinical Microbiology \& Infectious Diseases 


\section{Abstract}

18 A collection of 40 Bacillus (B.) anthracis strains mostly isolated from soil in Bulgaria between 1960

19 and 1980 were investigated. All strains were proven to be $B$. anthracis by culture and amplification of

20 a B. anthracis-specific chromosomal marker. PCR demonstrated that in 9 strains both virulence

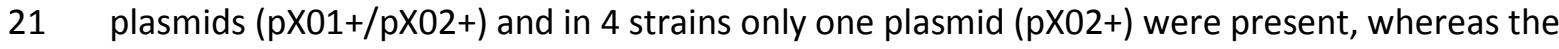

22 majority of strains ( $\mathrm{n}=27)$ lacked both plasmids (pX01-/pX02-). Multi-Locus-Variable Number of

23 Tandem Repeat-Analysis (MLVA) using 15 markers differentiated three genotypes. Comparison with

24 typing data of more than 1.000 different $B$. anthracis strains revealed that Bulgarian genotypes

25 affiliated with the A1.a cluster and form an own unique cluster different from clusters containing

26 strains isolated in geographical proximity like Turkey, Georgia, Hungary, Albania or Italy. In addition,

27 a new allele of one marker (vrrC2) was identified. Canonical Single Nucleotide Polymorphisms

28 analysis allocated 31 Bulgarian strains into the A.Br.008/009 and 9 strains into the A.Br.WNA group

29 which is the first description of $B$. anthracis strains of the A.Br.WNA group on the Eurasian continent. 
Bacillus (B.) anthracis, a gram-positive, aerobe, spore-forming bacterium is found throughout the world. It is the causative agent of anthrax, a disease of wild animals and domestic livestock, predominantly cattle and goats. Anthrax is a zoonotic disease and humans can be infected by virulent strains harboring the virulence plasmids pXO1 and pXO2. Depending on the route of infection, pulmonary or inhalational anthrax, gastrointestinal or cutaneous anthrax can develop and, if left untreated, especially in case of pulmonary anthrax, death may occur [1]. Spores of $B$. anthracis may persist in the soil for decades. Recently, spores have been used in bioterrorist attacks [2-5]. DNA-based typing tools have been developed to evaluate the diversity of $B$. anthracis isolates from different geographic areas. These studies have also been undertaken with a view to trace intentionally released strains back to their origins [5-7]. Multi-Locus-Variable Number of Tandem Repeat (VNTR)-Analysis (MLVA) became one of the major assays for molecular typing of $B$. anthracis $[8,9]$. Up-to-now, most strains are analyzed by MLVA using 15 loci, representing eleven chromosomal and four plasmid loci. Further progress in differentiating strains is increasingly being achieved by whole genome sequencing which efficiently identifies the rare SNPs present in $B$. anthracis [10]. Single nucleotide polymorphisms (SNPs) were identified which define twelve major clonal lineages [9]. A molecular typing strategy was presented which applies canonical-SNPs analysis and VNTR analysis using 15 markers. This strategy had been used to subtype a collection of 1,044 $B$. anthracis isolates from 42 countries and an extensive genotype data set was created. These analyses divided the isolates into three previously recognized major lineages $(A, B$, and $C)$, with further subdivision into 12 clonal groups and, finally, 221 unique MLVA15 genotypes. By this, the global spread and regional diversity of $B$. anthracis became more evident [9]. Whereas genotyping data from Western and Central European countries as well as from countries in the South and East of the Black Sea have been published $[8,11]$, there are no data available from the Bulgarian and Romanian area which forms a bridge between those regions. 
58

In this study we analyzed 40 Bulgarian $B$. anthracis strains, mostly isolated from soil, by canSNP

57 typing and MLVA15 and demonstrate that Bulgarian strains form a unique genetic cluster.

\section{Material and Methods}

\section{Bacterial strains}

A collection of $40 \mathrm{~B}$. anthracis strains were obtained from the Historical Collection of the Medical

Military Academy of Sofia, Bulgaria (table 1). Bulgaria is situated in the Eastern part of Europe on the Western shore of the Black Sea (figure 1). All strains have been isolated between 1960 and 1980 in different districts of Bulgaria from soil with the exception of two strains originating from cattle (isolate 3187 and 3186). The majority of the isolates $(n=27)$ were collected in the South and NorthEast of Bulgaria (regions of Jambol, Razgrad and Silistra). All strains were cultivated in a biosafety level 3 (BSL) laboratory on Columbia blood agar at $37^{\circ} \mathrm{C}$. Colony characteristics were in concordance with a B. anthracis-typical phenotype, i. e. flat, dull-grey, irregular bordered, sticky colonies with no hemolysis. DNA isolation was performed as previously described [12]. Strains were confirmed to be B. anthracis based on a positive amplification of the chromosomal target dhp61 [12]. Presence or absence of plasmids pXO1 and pXO2 was determined by amplifying fragments of the target genes pagA and capB using the RealTime PCR Bacillus anthracis - Detection Kit (Roche Diagnostics, Penzberg, Germany) according to the protocol of the manufacturer.

Multi-Locus-Variable Number of Tandem Repeat-Analysis (MLVA)

MLVA was done using 15 markers according to the protocol published by van Ert et al [9]. Platinum Taq polymerase, $\mathrm{MgCl}_{2}$ and water were purchased from Invitrogen (Karlsruhe, Germany) and Eppendorf (Hamburg, Germany), respectively. Primers were synthesized by Tib-MolBiol (Berlin, Germany). Multiplex-PCR reactions were performed using the Thermocycler GenAmp PCR System 9700 (Perkin Elmer, Waltham, USA). PCR products were purified using the PCR Purification Kit (Qiagen, Hilden, Germany) prior to loading on the ABI3100 sequencer (Applied Biosystems, 
Darmstadt, Germany). Fragment lengths were determined by comparison to the internal length

82 standard 1200LIZ (Applied Biosystems). Based on the size of the respective repeat unit and the

83 fragment length, a repeat copy number was calculated for each marker according to the algorithm

84 described by Vergnaud et al [13]. In order to compare data obtained in this study with typing data 85 described by van Ert et al. [9, 14] we determined the repeat copy number of each marker of their 86 strain collection after calibration with data of strains which had been analyzed in parallel in both 87 laboratories (strains A9, A22, A30, A40, A41, A66, A67) and by including the entire genome sequencing data of strains Ames A2010 and Vollum (AAAC01000001.1 and NZ_AAEP00000000, resp.). In some cases sequencing of amplicons was performed using the respective MLVA primers and BigDye Terminator chemistry (Applied Biosystems) on a $3100 \mathrm{ABI}$ sequencer (Applied Biosystems). The sequence of marker vrrC2 of strain 3189 was deposited in Genbank (accession number HM240285). Repeat units were identified by using the software Tandem Repeat (http://tandem.bu.edu/trf/trf.html). Data analysis was performed using the Software Bionumerics 5.1 (Applied Maths, Sint-Martens-Latem, Belgium). Cluster analysis was done using categorical coefficients and similarity trees based on the Unweighted Pair Group Method with Arithmetic mean (UPGMA) method.

\section{Canonical Single Nucleotide Polymorphisms (canSNP) Analysis}

CanSNP analysis was done according to van Ert et al. [9] with slightly modified probe sequences (see supplemental data, table 1), To further sub-classify strains belonging to the WNA cluster SNP analysis was performed according to Kenefic et al. [15]. All Primers and probes (supplemental data) were obtained from Tib-Molbiol (Berlin, Germany). PCR was performed with a final concentration of primers $(0.3 \mu \mathrm{M})$ and probes $(0.1 \mu \mathrm{M})$ using the ABI TaqMan-Mastermix (Applied Biosystems) and approx. 4 ng of template DNA using the MX3000 system (Stratagene, Agilent Technologies, Waldbronn, Germany). Initial denaturation at $96^{\circ} \mathrm{C}$ for $10 \mathrm{~min}$ was followed by 40 cycles, each consisting of denaturation $\left(30 \mathrm{sec}\right.$ at $\left.96^{\circ} \mathrm{C}\right)$, annealing $\left(30 \mathrm{sec}\right.$ at $\left.56^{\circ} \mathrm{C}\right)$ and elongation $(30 \mathrm{sec}$ at $72^{\circ} \mathrm{C}$ ). Data evaluation was done using the algorithm published by van Ert et al. [9]. 


\section{Results}

110 All Bulgarian strains could be identified as $B$. anthracis based on amplification of a $B$. anthracis-

111 specific chromosomal sequence targeted by the dhp61-PCR assay. 9 out of 40 strains, including strain 1123187 isolated from cattle, harbored both virulence plasmids (pXO1 and pXO2, respectively), whereas 1134 strains contained plasmid pXO2 only (see table 1). The 27 others lack both plasmids.

\section{MLVA-Typing}

115 UPGMA cluster analysis of the 9 Bulgarian strains containing both plasmids revealed three different genotypes designated GT1, GT2 and GT3 (table 1 and figure 2). GT2 consisting of 2 strains and GT3 consisting of 6 strains differ in the number of repeat copies of marker vrrA (10 versus 11 repeat copies) and marker pXO1 (7 versus 10 repeat copies). GT1 is represented by a single strain (3189) with an unique allele size for marker vrrC2. Sequencing confirmed that the fragment length of marker vrrC2 is indeed much lower (333 bp) as compared to already described fragment lengths ranging from $458 \mathrm{bp}$ to $635 \mathrm{bp}$. This allele (HM240285) is coded 6 in agreement with the currently used convention in which the $532 \mathrm{bp}$ allele present in the sequenced Ames genome when using the same primer set is coded 17 [9].

Analysis of four strains containing only plasmid pX02 (i.e. strains 3188, 3171, 3167 and 3180) allowed differentiation of two genotypes designated GT2a and GT3a, respectively. These strains have identical repeat codes with respect to the 11 chromosomal (the "chromosomal backbone") and the 3 plasmid pX02-specific markers as strains with both plasmids belonging to GT2 and GT3 (table 1). Likewise, all plasmid-less strains $(n=27)$ belong to 2 genotypes designated GT2b and GT3b because the 11 chromosomal markers are identical as compared to strains of the genotypes GT2 and GT3 (table 1). 
131 Clustering resulted in a similarity tree shown in figure 2. Because of identical repeat codes for the 11

chromosomal markers all strains clustered closely with either genotype GT2 or GT3. This variation is shown in boxed profiles with either GT2, GT2a and GT2b or GT3, GT3a and GT3b, respectively (figure 2).

MLVA-data in a global context

To put typing results of Bulgarian strains in a more global context, a modUPGMA analysis of all MLVA datasets $(n=40)$ was conducted with already published datasets. To this end we included MLVA data of 1,044 B. anthracis strains described by van Ert et al. and 148 strains of our in-house collection. The analysis demonstrated that the three genotypes GT1, GT2 and GT3 as well as the four "subgenotypes" GT2a, GT2b, GT3a and GT3b are novel and cluster separately (figure 3). According to the MLVA15 system of van Ert et al., they all represent a new sub-cluster within the A1.a cluster. Strains collected in countries located in the South and East of Bulgaria, such as Georgia, Turkey and Iran, belong to the South Caucasian A3.a cluster [8]. In contrast, strains isolated in countries in the West of Bulgaria, such as Albania, Hungary [9] and Italy [16] form a different sub-cluster within the A1.a cluster (figure 3). The highest similarity of the Bulgarian cluster is seen with the WNA-cluster (figure 3) consisting of strains exclusively isolated in Canada and in the Northern States of the US [9, 17]. Both clusters differ in the repeat copy number of three markers of the "chromosomal backbone" (VNTR12, VNTR19 and VNTR32). This is shown with a representative strain (A1119USA) of the WNAcluster in Figure 2.

canSNP-Typing

CanSNP analysis separated the Bulgarian isolates into two different phylogenetic groups. 9 out of 40 strains (see table 1) belong to the A.Br.WNA group, whereas 31 strains belong to the A.Br.008/009 
group. It is interesting to note that genotypes GT2b and GT3b are found in both, the A.Br.WNA and the A.Br.008/009 group. To further sub-classify the Bulgarian WNA-strains we used a SNP-based strategy described by Kenefic et al. [15] and determined the nucleotides T, C, and A for the SNPs wna237471, wna1141774 and wna3368524, respectively. Based on this unique signature the 9 Bulgarian WNA strains could not be classified in one of those six WNA-sub-clades described by Kenefic et al. [15].

\section{Discussion}

163 The actual method used for forensic investigations of $B$. anthracis strains and isolates is based on a 164 typing strategy called "progressive hierarchical resolving assay using nucleic acids" (PHRANA) 165 introduced by Keim et al. [18]. This strategy proposes in a first step to determine the canSNP group 166 and in a second step to conduct MLVA.

167 canSNP-Typing

168 An unexpected result of the canSNP typing described here was that Bulgarian $B$. anthracis strains 169 could be divided into two distinct canSNP groups, i.e. A.Br.008/009 and A.Br.WNA. According to our 170 findings 9 out of 40 Bulgarian strains (all derived from soil) belong to canSNP group A.Br.WNA which 171 is the first description of A.Br.WNA strains on the Eurasian continent. Based on typing data described 172 in the literature for South-Caucasian strains from Georgia and Turkey [8] and for strains from 173 Kazakhstan [11] we had assumed that Bulgarian strains would belong to the canSNP group 174 A.Br.008/009. To further sub-classify WNA strains Kenefic et al. [15] had investigated DNA of 352 175 WNA-strains (according to van Ert et al.) and showed that 351 WNA-strains could be sub-classified 176 into 6 distinct WNA-sub-clades. One strain (\#2000032989), however, derived from a historical 177 collection hold at CDC could not be grouped [15]. SNP analysis of the Bulgarian WNA-strains revealed 178 identical SNPs as this strain for the investigated three nucleotide positions. The explanation that 179 trading of contaminated animal products from North America has established a focus of A.Br.WNA 
strains in Bulgaria is highly unlikely. Instead, the most parsimonious explanation is homoplasy of the

WNA-specific point mutation: The same A.Br.WNA-specific mutation has occurred in the Bulgarian area as it had led to the formation of canSNP group A.Br.WNA in North America from its ancestor group A.Br.008/009. Differences in three chromosomal MLVA-markers observed between

"American" representatives of the A.Br.WNA-SNP-group and Bulgarian-WNA-isolates support this theory and genome sequencing of a Bulgarian strain of the WNA cluster might improve our knowledge with respect to classification.

187 Homoplasy, which is very rarely seen in B. anthracis ( 1 in $>25.0000$ data points), has already been postulated to have occurred for strain A0303: this strain has been allocated to the WNA-clade although canSNP 2589947 shows the ancestral A type instead of the G expected in the WNA clade $[15,19]$

\section{MLVA-Typing}

Historically, MLVA typing of B. anthracis strains started in the year 2000 and was based on eight markers (6 chromosomal and one plasmid marker each) which allowed the discrimination of 89 different genotypes out of 400 isolates [20]. Based on this $1^{\text {st }}$ generation typing system, all Bulgarian strains have the identical MLVA profile with regard to the 6 chromosomal marker as strain A1119USA of the WNA-cluster [9], recently published Kazakh strains [11] and five genotypes of the MLVA8 system [20] (GT1, 2, 4, 5, 13 and 14). A few years later two different extensions of the MLVA8 system were developed by Le Fléche et al., Lista et al. and van Ert et al. [9, 21, 22] and are still in use for typing. The MLVA25 system described by Lista et al. showed a high discriminatory power especially for strains of their European collection. The MLVA15 system introduced by van Ert et al. was applied to 1,044 strains and contributed significantly to the understanding of the geographical diversity of $B$. anthracis in the world. Analysis of the Bulgarian strains with the MLVA15 system yielded a higher 204 discriminatory power as compared to the MLVA8 system: Differences could be observed in three 
chromosomal markers (vrrA, vrrC2, BaVNTR32) between the Bulgarian and the WNA-cluster, whereas the patterns only show only up to two differences dependent on the strain investigated (figure 2).

In a given geographic location strains of $B$. anthracis may have different origins. Either the strains are indeed genuine for this region or they had been imported into the region from other areas by animal or human factors, such as trading. Investigation of spores collected in a Belgian wool factory [23] and retrospective investigations of outbreaks in Switzerland in 1979 [24] show, that the outbreaks could be linked to spore-contaminated wool either from Kazakhstan or the Middle East. These examples highlight that only accurate and detailed information about an outbreak can identify its real origin. Typing data derived from a strain with no further information do not necessarily contribute to the understanding of the global diversity of anthrax.

215 An interesting option to identify genuine strains of a given geographical region is to analyze soil216 associated $B$. anthracis strains. It is known that strains may lack one or even both plasmids [25] after 217 long-term-storage based on repeated passage, instead of lyophilization. We assume that with Bulgarian collection, a loss of plasmids had occurred over the years resulting in 27 plasmid-less strains out of 40 strains.

220 However, using the existing algorithms based on a categorical coefficient and an "unweighted pair 221 group mean arithmetic-analysis", plasmid-less strains or strains lacking one plasmid would be 222 grouped into different clusters distinct to strains with the identical chromosomal backbone and 223 plasmids (data not shown).

224 This results in false clustering of plasmid-less strains in the UPGMA dendrogram. Up to now this 225 mathematical problem has not been discussed yet, because only a few genotypes of plasmid-less 226 strains are part of analyses described, e.g. 7 GTs out of 221 GT [9]. In the context of the "global" $B$. 227 anthracis collection of van Ert et a.l [9] consequences of false clustering were not obvious for the 228 authors. In our geographically rather limited collection consequences of false clustering stand out. By 229 using the feature of the categorical coefficient clustering of Bionumerics 5.1 missing markers are 
ignored and the data analysis is based on chromosomal markers only. As a consequence, all strains

with the same chromosomal background cluster together (boxed genotypes in figure 2) and are assigned as subgroups of the respective genotypes. A typing system relying on chromosomal markers only seems to be useful for epidemiology and interpretation of diversity, in forensic investigations of virulent $B$. anthracis strains all typing data have to be taken into account.

\section{Molecular evolution in Bulgaria}

Data interpretation of epidemiologically relevant MLVA profiles in combination with phylogenetically relevant results of the canSNP typing revealed an interesting finding. B. anthracis strains with genotypes GT2b and GT3b, lacking plasmid markers, are present in both canSNP groups A.Br.008/009 and A.Br.WNA. A similar finding has been reported by Simonson et al. [17]. They identified the

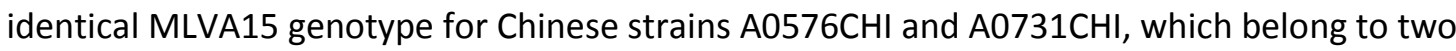
different canSNP groups (A.Br.Ames and A.Br.001/002, respectively). With regard to phylogeny this points to two different populations existing in the same area. Against the background of different mutation frequencies of MLVA markers and canSNPs, it has to be assumed, that first the mutation of the SNP occurred resulting in two different populations in Bulgaria. Lateron, MLVA markers evolved in parallel. The Bulgarian and the Chinese data demonstrate that MLVA and canSNP typing do not always led to the same result. Therefore, interpretation of only MLVA-based typing results with regard to phylogeny has to be performed with caution.

\section{Conclusion:}

249 In this study we demonstrate that Bulgarian B. anthracis strains form a geographically separated 250 cluster with 3 unique MLVA genotypes different from genotypes found in neighboring countries. In 251 addition, canSNP analysis differentiated Bulgarian B. anthracis strains into two groups, i.e. the 252 A.Br.008 and the A.Br.WNA group, represented by a new WNA sub-clade. This the first description of 253 A.Br.WNA strains on the Eurasian continent. The genetic typing data provided here, including data of 254 strains lacking either one or both plasmids, increase our knowledge of the diversity of $B$. anthracis in 
255 the Black Sea-region and may help to extend the understanding of the global distribution and genetic

1

\section{Acknowledgment}

259 We gratefully acknowledge Claudia Kahlhofer and Linda Dobrzykowski for excellent technical 260 assistance. We also thank the unknown reviewers for helpful comments.

\section{References}

262 [1] WHO (2008) Anthrax in humans and animals.

263 http://www.who.int/csr/resources/publications/AnthraxGuidelines2008/en/index.html, WHO 264 Library Cataloguing, Accessed 11 December 2010

265 [2] Greene CM, Reefhuis J, Tan C, Fiore AE, Goldstein S, Beach MJ, Redd SC, Valiante D, Burr G, 266 Buehler J, Pinner RW, Bresnitz E, Bell BP (2002) Epidemiologic investigations of bioterrorism-related 267 anthrax, New Jersey, 2001. Emerg Infect Dis 8:1048-1055

268 [3] Holtz TH, Ackelsberg J, Kool JL, Rosselli R, Marfin A, Matte T, Beatrice ST, Heller MB, Hewett 269 D, Moskin LC, Bunning ML, Layton M (2003) Isolated case of bioterrorism-related inhalational 270 anthrax, New York City, 2001. Emerg Infect Dis 9:689-696

271 [4] Jernigan JA, Stephens DS, Ashford DA, Omenaca C, Topiel MS, Galbraith M, Tapper M, Fisk TL, 272 Zaki S, Popovic T, Meyer RF, Quinn CP, Harper SA, Fridkin SK, Sejvar JJ, Shepard CW, McConnell M, 273 Guarner J, Shieh WJ, Malecki JM, Gerberding JL, Hughes JM, Perkins BA (2001) Bioterrorism-related 274 inhalational anthrax: the first 10 cases reported in the United States. Emerg Infect Dis 7:933-944

275 [5] Keim P, Smith KL, Keys C, Takahashi H, Kurata T, Kaufmann A (2001) Molecular investigation 276 of the Aum Shinrikyo anthrax release in Kameido, Japan. J Clin Microbiol 39:4566-4567

277 [6] Takahashi H, Keim P, Kaufmann AF, Keys C, Smith KL, Taniguchi K, Inouye S, Kurata T (2004) 278 Bacillus anthracis incident, Kameido, Tokyo, 1993. Emerg Infect Dis 10:117-120 
[7] Van Ert MN, Easterday WR, Simonson TS, U'Ren JM, Pearson T, Kenefic LJ, Busch JD, Huynh

LY, Dukerich M, Trim CB, Beaudry J, Welty-Bernard A, Read T, Fraser CM, Ravel J, Keim P (2007)

Strain-specific single-nucleotide polymorphism assays for the Bacillus anthracis Ames strain. J Clin Microbiol 45:47-53

[8] Merabishvili M, Natidze M, Rigvava S, Brusetti L, Raddadi N, Borin S, Chanishvili N, Tediashvili

M, Sharp R, Barbeschi M, Visca P, Daffonchio D (2006) Diversity of Bacillus anthracis strains in

Georgia and of vaccine strains from the former Soviet Union. Appl Environ Microbiol 72:5631-5636

[9] Van Ert MN, Easterday WR, Huynh LY, Okinaka RT, Hugh-Jones ME, Ravel J, Zanecki SR, Pearson T, Simonson TS, U'Ren JM, Kachur SM, Leadem-Dougherty RR, Rhoton SD, Zinser G, Farlow J, Coker PR, Smith KL, Wang B, Kenefic LJ, Fraser-Liggett CM, Wagner DM, Keim P (2007) Global genetic population structure of Bacillus anthracis. PloS one 2:e461

[10] Kuroda M, Serizawa M, Okutani A, Sekizuka T, Banno S, Inoue S (2010) Genome-wide single nucleotide polymorphism typing method for identification of Bacillus anthracis species and strains among B. cereus group species. J Clin Microbiol 48:2821-2829

[11] Aikembayev AM, Lukhnova L, Temiraliyeva G, Meka-Mechenko T, Pazylov Y, Zakaryan S, 294 Denissov G, Easterday WR, Van Ert MN, Keim P, Francesconi SC, Blackburn JK, Hugh-Jones M, 295 Hadfield T (2010) Historical distribution and molecular diversity of Bacillus anthracis, Kazakhstan. 296 Emerg Infect Dis 16:789-796

[12] Antwerpen M, Zimmermann P, Frangoulidis D, Bewley K, Meyer H (2008) Real-time PCR system targeting a chromosomal marker specific for Bacillus anthracis. Mol Cell Probes 22:313-315 299 [13] Vergnaud G, Pourcel C (2006) Multiple Locus VNTR (Variable Number of Tandem Repeat) 300 Analysis (MLVA). In: E S (ed) Molecular Identification, Systematics and Population Structure of 301 Prokaryotes. Springer Publishing, pp 83-104

302 [14] Keim P, Kalif A, Schupp J, Hill K, Travis SE, Richmond K, Adair DM, Hugh-Jones M, Kuske CR, 303 Jackson P (1997) Molecular evolution and diversity in Bacillus anthracis as detected by amplified 304 fragment length polymorphism markers. J Bacteriol 179:818-824 
WK, Beaudry JA, Jiang L, Gajer P, Foster JT, Mead JI, Ravel J, Keim P (2009) Pre-Columbian origins for North American anthrax. PloS one 4:e4813

[16] Fasanella A, Van Ert M, Altamura SA, Garofolo G, Buonavoglia C, Leori G, Huynh L, Zanecki S, Keim P (2005) Molecular diversity of Bacillus anthracis in Italy. J Clin Microbiol 43:3398-3401

[17] Simonson TS, Okinaka RT, Wang B, Easterday WR, Huynh L, U'Ren JM, Dukerich M, Zanecki

SR, Kenefic LJ, Beaudry J, Schupp JM, Pearson T, Wagner DM, Hoffmaster A, Ravel J, Keim P (2009)

Bacillus anthracis in China and its relationship to worldwide lineages. BMC Microbiol 9:71

[18] Keim P, Van Ert MN, Pearson T, Vogler AJ, Huynh LY, Wagner DM (2004) Anthrax molecular epidemiology and forensics: using the appropriate marker for different evolutionary scales. Infect Genet Evol 4:205-213

[19] Pearson T, Busch JD, Ravel J, Read TD, Rhoton SD, U'Ren JM, Simonson TS, Kachur SM,

Leadem RR, Cardon ML, Van Ert MN, Huynh LY, Fraser CM, Keim P (2004) Phylogenetic discovery bias in Bacillus anthracis using single-nucleotide polymorphisms from whole-genome sequencing. Proc Natl Acad Sci U S A 101:13536-13541

[20] Keim P, Price L, Klevytska A, Smith K, Schupp J, Okinaka R, Jackson P, Hugh-Jones M (2000) Multiple-locus variable-number tandem repeat analysis reveals genetic relationships within Bacillus anthracis. J Bacteriol 182:2928-2936

[21] Le Fléche P, Hauck Y, Oteniente L, Prieur A, Denoeud F, Ramisse V, Sylvestre P, Benson G, 324 Ramisse F, Vergnaud G (2001) A tandem repeat database for bacterial genomes: application to the 325 genotyping of Yersinia pestis and Bacillus anthracis. BMC Microbiol 1:2 326 [22] Lista F, Faggioni G, Valjevac S, Ciammaruconi A, Vaissaire J, le Doujet C, Gorge O, De Santis R, 327 Carattoli A, Fasanella A, Orsini F, D'Amelio R, Pourcel C, Cassone A, Vergnaud G (2006) Genotyping of 328 Bacillus anthracis strains based on automated capillary 25-loci multiple locus variable-number 329 tandem repeats analysis. BMC Microbiol 6:33 
[23] Wattiau P, Klee SR, Fretin D, Van Hessche M, Ménart M, Franz T, Chasseur C, Butaye $P$,

Imberechts H (2008) Occurence and genetic diversity of Bacillus anthracis strains isolated in an active wool-cleaning fcatory. Appl Environ Microbiol 74:4005-4011

[24] Pilo P, Perreten V, Frey J (2008) Molecular epidemiology of Bacillus anthracis: determining the correct origin. Appl Environ Microbiol 74:2928-2931

[25] Marston CK, Hoffmaster AR, Wilson KE, Bragg SL, Plikaytis B, Brachman P, Johnson S, Kaufmann AF, Popovic T (2005) Effects of long-term storage on plasmid stability in Bacillus anthracis. Appl Environ Microbiol 71:7778-7780

Table 1: Variable Number of Tandem Repeat sizes for 40 Bulgarian Bacillus anthracis strains.

\#Analysis was performed according to van Ert et al. [9] and the repeat codes were calculated

according to Vergnaud et al. [13].

*fragment length which has not been described so far for allele vrrC2.

$\S$ isolated from cattle

Figure 1: Map of Europe with Bulgaria located on the Western shore of the Black Sea. genotypes with respective sub-branches.

Figure 3: Dendrogram based on MLVA typing data of 1.191 Bacillus anthracis strains and isolates 353 using the modUPGMA-clustering method. MLVA clusters were assigned normal letters, geographical 354 associated clusters are in italic letters. 

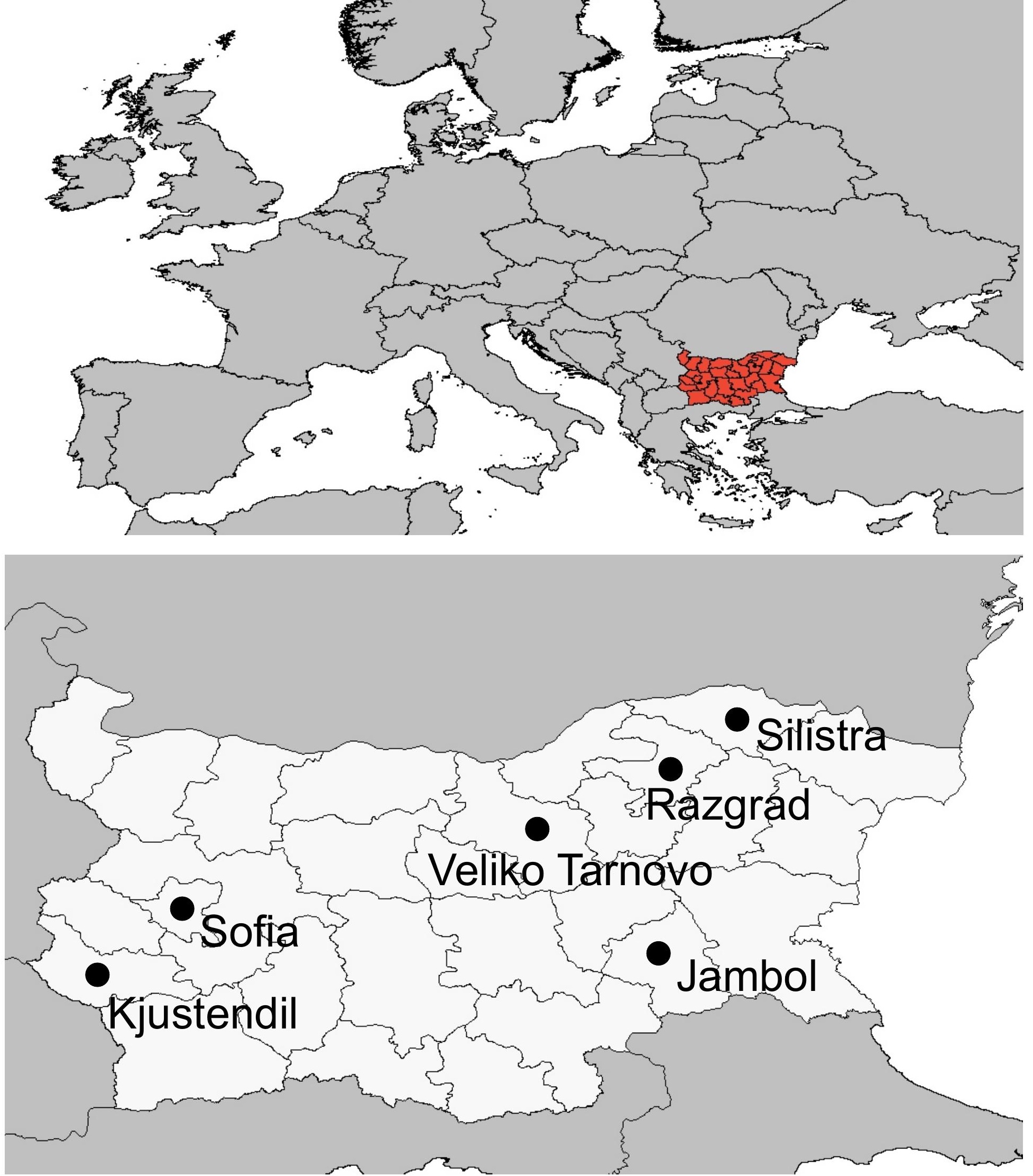


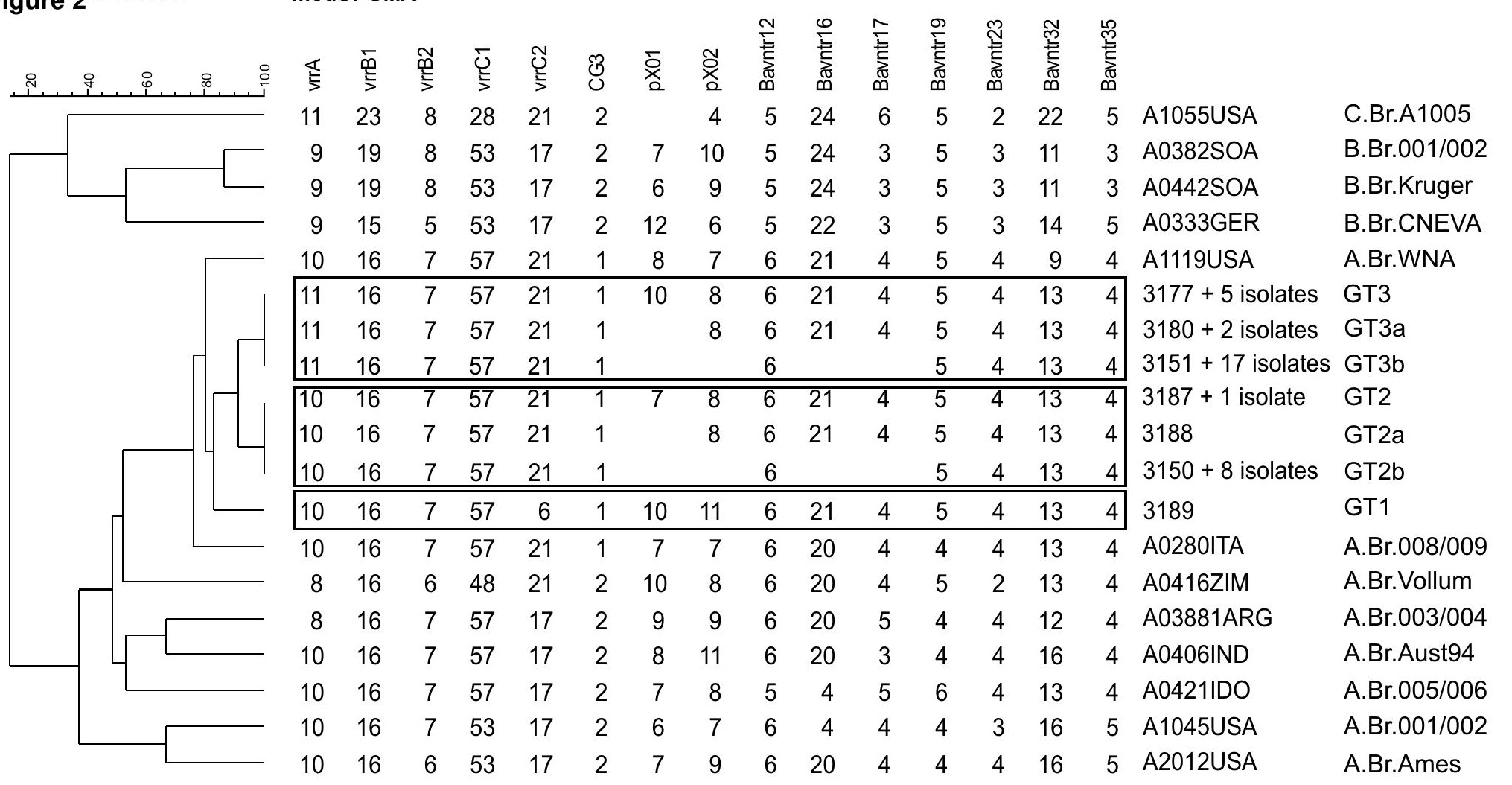


Figure 3

Click here to download high resolution image

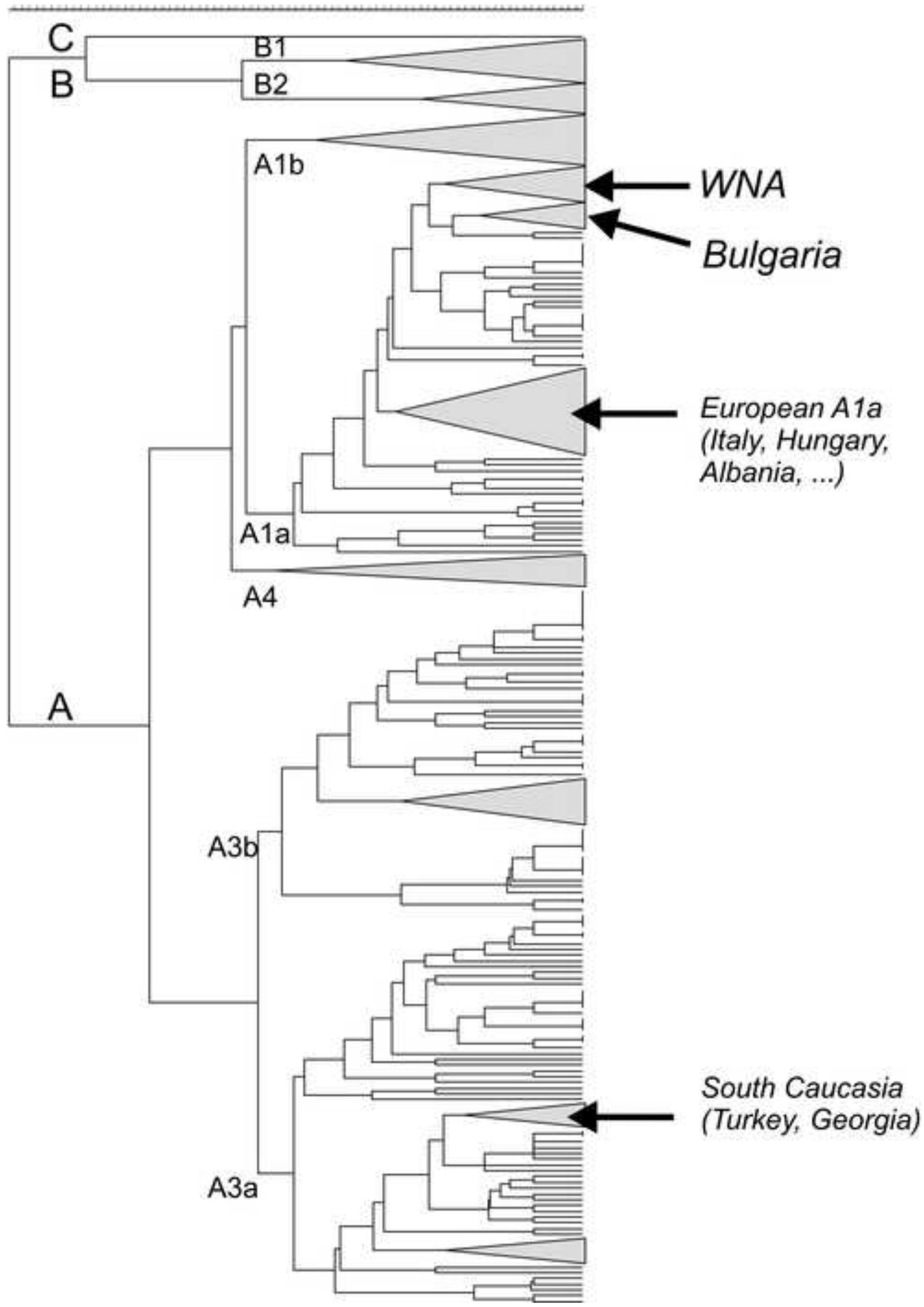

South Caucasia (Turkey, Georgia) 


\begin{tabular}{|c|c|c|c|c|c|c|c|c|c|c|c|c|c|c|c|c|c|}
\hline $\begin{array}{ll}\text { designation district } & \end{array}$ & canSNP & MLVA-Genotype & vrrA & vrrB1 & vrrB2 & vrrC1 & vrrC2 & CG3 & pX01 & pX02 & BaVNTR12 & BaVNTR16 & BaVNTR17 & BaVNTR19 & BaVNTR23 & BaVNTR32 & BaVNTR35 \\
\hline 3189 Sofia & \multirow{31}{*}{ 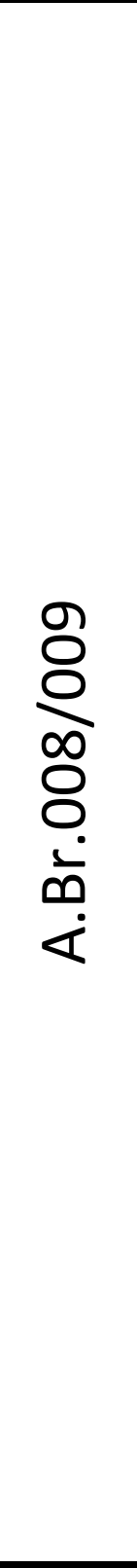 } & GT1 & 10 & 16 & 7 & 57 & $6^{*}$ & 1 & 10 & 11 & 6 & 21 & 4 & 5 & 4 & 13 & 4 \\
\hline$\S 3187$ Kjustendil & & \multirow{2}{*}{ GT2 } & 10 & 16 & 7 & 57 & 21 & 1 & 7 & 8 & 6 & 21 & 4 & 5 & 4 & 13 & 4 \\
\hline 3185 Sofia & & & 10 & 16 & 7 & 57 & 21 & 1 & 7 & 8 & 6 & 21 & 4 & 5 & 4 & 13 & 4 \\
\hline 3188 Sofia & & GT2a & 10 & 16 & 7 & 57 & 21 & 1 & & 8 & 6 & 21 & 4 & 5 & 4 & 13 & 4 \\
\hline 3170 Silistra & & GT2b & 10 & 16 & 7 & 57 & 21 & 1 & & & 6 & & & 5 & 4 & 13 & 4 \\
\hline 3179 Silistra & & \multirow{6}{*}{ GT3 } & 11 & 16 & 7 & 57 & 21 & 1 & 10 & 8 & 6 & 21 & 4 & 5 & 4 & 13 & 4 \\
\hline 3177 Silistra & & & 11 & 16 & 7 & 57 & 21 & 1 & 10 & 8 & 6 & 21 & 4 & 5 & 4 & 13 & 4 \\
\hline 3168 Tarnovo & & & 11 & 16 & 7 & 57 & 21 & 1 & 10 & 8 & 6 & 21 & 4 & 5 & 4 & 13 & 4 \\
\hline 3166 Tarnovo & & & 11 & 16 & 7 & 57 & 21 & 1 & 10 & 8 & 6 & 21 & 4 & 5 & 4 & 13 & 4 \\
\hline $3165 \mathrm{Jambol}$ & & & 11 & 16 & 7 & 57 & 21 & 1 & 10 & 8 & 6 & 21 & 4 & 5 & 4 & 13 & 4 \\
\hline $3161 \mathrm{Jambol}$ & & & 11 & 16 & 7 & 57 & 21 & 1 & 10 & 8 & 6 & 21 & 4 & 5 & 4 & 13 & 4 \\
\hline 3171 Silistra & & \multirow{3}{*}{ GT3a } & 11 & 16 & 7 & 57 & 21 & 1 & & 8 & 6 & 21 & 4 & 5 & 4 & 13 & 4 \\
\hline 3180 Silistra & & & 11 & 16 & 7 & 57 & 21 & 1 & & 8 & 6 & 21 & 4 & 5 & 4 & 13 & 4 \\
\hline 3167 Tarnovo & & & 11 & 16 & 7 & 57 & 21 & 1 & & 8 & 6 & 21 & 4 & 5 & 4 & 13 & 4 \\
\hline 3184 Sofia & & \multirow{17}{*}{ GT3b } & 11 & 16 & 7 & 57 & 21 & 1 & & & 6 & & & 5 & 4 & 13 & 4 \\
\hline 3183 Sofia & & & 11 & 16 & 7 & 57 & 21 & 1 & & & 6 & & & 5 & 4 & 13 & 4 \\
\hline 3182 Sofia & & & 11 & 16 & 7 & 57 & 21 & 1 & & & 6 & & & 5 & 4 & 13 & 4 \\
\hline 3176 Silistra & & & 11 & 16 & 7 & 57 & 21 & 1 & & & 6 & & & 5 & 4 & 13 & 4 \\
\hline 3175 Silistra & & & 11 & 16 & 7 & 57 & 21 & 1 & & & 6 & & & 5 & 4 & 13 & 4 \\
\hline 3178 Silistra & & & 11 & 16 & 7 & 57 & 21 & 1 & & & 6 & & & 5 & 4 & 13 & 4 \\
\hline 3164 Jambol & & & 11 & 16 & 7 & 57 & 21 & 1 & & & 6 & & & 5 & 4 & 13 & 4 \\
\hline $3163 \mathrm{Jambol}$ & & & 11 & 16 & 7 & 57 & 21 & 1 & & & 6 & & & 5 & 4 & 13 & 4 \\
\hline 3162 Jambol & & & 11 & 16 & 7 & 57 & 21 & 1 & & & 6 & & & 5 & 4 & 13 & 4 \\
\hline 3181 Sofia & & & 11 & 16 & 7 & 57 & 21 & 1 & & & 6 & & & 5 & 4 & 13 & 4 \\
\hline 3160 Razgrad & & & 11 & 16 & 7 & 57 & 21 & 1 & & & 6 & & & 5 & 4 & 13 & 4 \\
\hline 3159 Razgrad & & & 11 & 16 & 7 & 57 & 21 & 1 & & & 6 & & & 5 & 4 & 13 & 4 \\
\hline 3158 Razgrad & & & 11 & 16 & 7 & 57 & 21 & 1 & & & 6 & & & 5 & 4 & 13 & 4 \\
\hline 3156 Jambol & & & 11 & 16 & 7 & 57 & 21 & 1 & & & 6 & & & 5 & 4 & 13 & 4 \\
\hline 3154 Razgrad & & & 11 & 16 & 7 & 57 & 21 & 1 & & & 6 & & & 5 & 4 & 13 & 4 \\
\hline 3152 Jambol & & & 11 & 16 & 7 & 57 & 21 & 1 & & & 6 & & & 5 & 4 & 13 & 4 \\
\hline 3151 Jambol & & & 11 & 16 & 7 & 57 & 21 & 1 & & & 6 & & & 5 & 4 & 13 & 4 \\
\hline 3174 Silistra & \multirow{9}{*}{$\underset{\frac{1}{\infty}}{\sum_{\dot{\tau}}}$} & \multirow{8}{*}{ GT2b } & 10 & 16 & 7 & 57 & 21 & 1 & & & 6 & & & 5 & 4 & 13 & 4 \\
\hline 3173 Silistra & & & 10 & 16 & 7 & 57 & 21 & 1 & & & 6 & & & 5 & 4 & 13 & 4 \\
\hline 3172 Silistra & & & 10 & 16 & 7 & 57 & 21 & 1 & & & 6 & & & 5 & 4 & 13 & 4 \\
\hline 3150 Jambol & & & 10 & 16 & 7 & 57 & 21 & 1 & & & 6 & & & 5 & 4 & 13 & 4 \\
\hline $3157 \mathrm{Jambol}$ & & & 10 & 16 & 7 & 57 & 21 & 1 & & & 6 & & & 5 & 4 & 13 & 4 \\
\hline 3155 Jambol & & & 10 & 16 & 7 & 57 & 21 & 1 & & & 6 & & & 5 & 4 & 13 & 4 \\
\hline 3153 Razgrad & & & 10 & 16 & 7 & 57 & 21 & 1 & & & 6 & & & 5 & 4 & 13 & 4 \\
\hline$\S 3186$ Sofia & & & 10 & 16 & 7 & 57 & 21 & 1 & & & 6 & & & 5 & 4 & 13 & 4 \\
\hline 3169 Tarnovo & & GT3b & 11 & 16 & 7 & 57 & 21 & 1 & & & 6 & & & 5 & 4 & 13 & 4 \\
\hline
\end{tabular}


Electronic Supplementary Material
Click here to download Electronic Supplementary Material: supplementary data .xls

Electronic Supplementary Material
Click here to download Electronic Su

(a) 